\title{
Effects of Deficit Irrigation Strategy and Foliar Application of Salicylic Acid on Growth of Jatropha curcas L.
}

\author{
Hokam, E. M. ${ }^{1}$ and Abo El-Soud, I. H. ${ }^{2}$ \\ ${ }^{1}$ Soil and Water Dept., Fac. of Agri., Suez Canal Univ., Egypt. 41522 \\ ${ }^{2}$ Hort. Dept., Fac. of Agri., Suez Canal Univ., Egypt, 41522
}

Received: $8 / 3 / 2017$

\begin{abstract}
At present, irrigated agriculture will take place under inadequate water incompetency. In this research the interaction between deficit irrigation (DI) and spraying Jatropha shrubs grown in sandy soil with salicylic acid (SA) to have a significant impact on increasing its adoption to water-limited areas was studied. Irrigation process included three levels of water regime, DI. In the first level, soil was irrigated up to full field capacity (0.0-DI), in the second, soil was irrigated up to 0.65 of full field capacity (0.35-DI), and up to 0.4 of full field capacity for the third level, representing 0.60-DI. Also, Jatropha plants were foliar sprayed with three levels of SA as 0.0, 5.0 and $10 \mathrm{mM}$. SA application at the rate of $5 \mathrm{mM}$ enhanced vegetative growth. The optimum treatment on growth characters was found when plants irrigated with fresh water at 0.35 -DI without significant difference with those at 0.0 -DI treatments. Also, SA application either at 5.0 or $10.0 \mathrm{mM}$ resulted in negative impact on plant growth, when plants subjected to 0-DI. The obtained results indicated that, following 0.35-DI strategy, great amounts of irrigation water could be saved and reached minimally $206 \mathrm{~L} \mathrm{plant}^{-1}$ years ${ }^{-1}$ at $2^{\text {nd }}$ year $\left(144 \mathrm{~m}^{3}\right.$ feddan $\left.{ }^{-1}\right)$.
\end{abstract}

Keywords: Jatropha curcas, biofuel plants, deficit irrigation, salicylic acid

\section{INTRODUCTION}

Nowadays, in spite of deficit irrigation is extensively practiced over millions of hectares, it has not received enough mindfulness attention in research. There is a vision for remodeling water productivity in many crops and there is sufficient information for designate the best deficit irrigation scenarios for different locations. Regulated deficit irrigation in some shrubs and trees dispelled that it not only increases water productivity, but also increase producer's income (Fereres and Soriano, 2007).

Irrigated agriculture accounts for three-quarters of global water withdrawals and therefore causes a global water scarcity. The amount of water to be withdrawn for biofuel production would increase (Hoogeveen et al., 2009). Production of biofuel and consumption has been rapidly growing in the last few years. Water scarcity is one of the major constraints of future potential production of second generation biofuels e.g., Jatropha (Pullaiah and Bahadur, 2013). Optimal amounts of water at the right time are crucial for ideal plant growth and production. Water use in the feedstock production phase is the biggest unknown factor when quantifying the water used in biofuel production (Jewitt et al., 2009).

Jatropha curcas (Euphorbiaceae family), is a deciduous, perennial plant; monoecious shrub and being promoted as a biofuel feedstock with common names: physic nut, curcas bean, purge nut, purging nut (Dehgan, 2012). A low water efficiency of Jatropha when compared to other feedstock sources was reported by Rajagopal and Zilberman (2007). J. curcas as an extremely hardy drought tolerant plant" has been promoted as ideal plant for cultivation on nonagricultural lands, thereby not competing with the lands for food production, in order to get good seed yield for oil production, the plant needs irrigation (Ahmad and Sultan, 2015).
Drought stress can significantly reduce photosynthesis and photosynthetic pigments, and eventually lead to reduction in plant growth. Drought stress occurs when the available water in the soil is reduced and atmospheric conditions cause continuous loss of water through transpiration or evaporation (Hasanuzzaman et al., 2013). Effect of soil moisture content on growth and yield in Jatropha was covered in some studies, Jayasundara et al. (2014) found that decreasing soil moisture content at early growth stage up to $50-60 \%$ (depletion level) was negatively affected the vegetative plant growth. On the other hand, PérezVazquez et al. (2013) found that total dry matter and chlorophyll at 40,60 and $80 \%$ soil water content (SWC) were statistically similar. In arid regions where irrigation is the most limited factor for crop production, it is imperative to have complete information for economic production of Jatropha for maximum utilization. Similar results were obtained by Kumar and Sharma (2008). The application of salicylic acid has reported to induce tolerance in plants to many biotic and abiotic stresses (Sahu, 2013). Especially, the significance of salicylic acid (SA) has been increasingly recognized in improved plant abiotic stress-tolerance via plant-metabolic processes (Khan et al., 2015). Salicylic acid has been shown to improve plant tolerance to major abiotic stresses such as drought (Fayez and Bazaid, 2014).

Little information has been generated related to the effect of water stress on growth and yield in Jatropha. Indeed, no quantitative data on water demand. The objectives of this study was to evaluate the growth of $J$. curcas grown at three different levels of regular deficit irrigation, after sprayed with different rates of salicylic acid.

\section{MATERIALS AND METHODS}

A field study was carried out at the Horticultural farm, Suez Canal Univ., Egypt, from 2012 to 2013 on 
sandy soil and the physical and chemical properties of experimental site soil are presented in Table (1). This experiment has been carried out at the juvenile stage of Jatropha from transplanting to the end of the second year (stage without bearing fruits). Jatropha seeds were planted directly in the soil in Mid October, 2011 at 2.5 $\mathrm{m} \times 2.5 \mathrm{~m}$ spacing.
The environmental conditions during experiments Meteorological data (from 2012 to 2013) was obtained from metrological Ismailia Central Lab. Data obtained were used to calculate the potential evapotranspiration $\left(\mathrm{ET}_{\mathrm{o}}\right)$ by Penman-Monteith equation using crop coefficient, $\mathrm{K}_{\mathrm{c}}$, for Jatropha plants in Ismailia obtained empirically, by Hokam and Abo ElSoud (2016).

Table (1): Some physical and chemical properties of soil

Physical properties

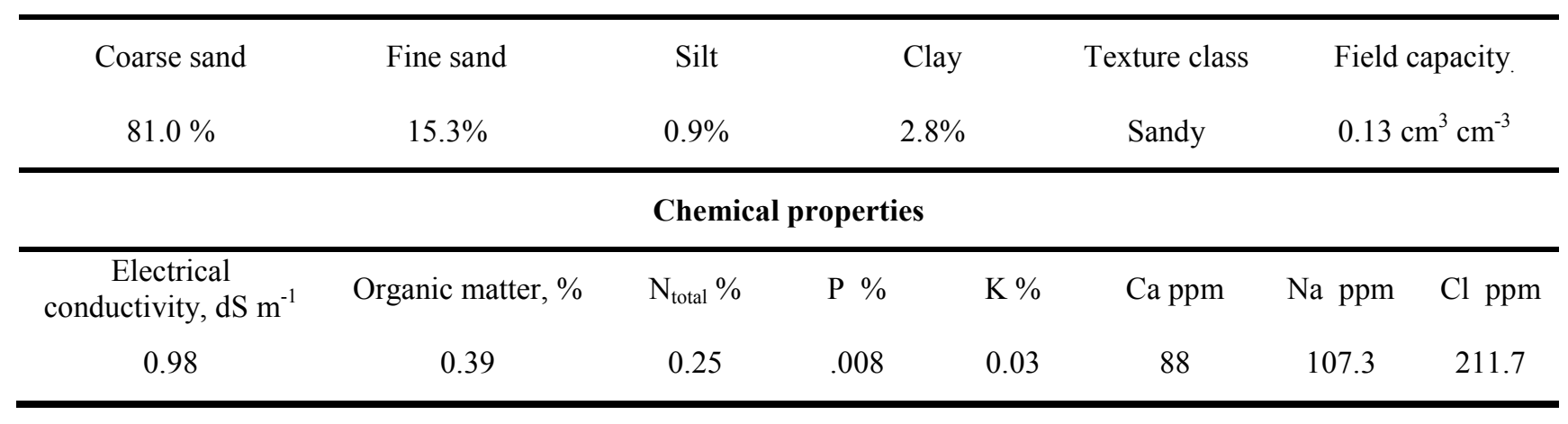

\section{Water Irrigation}

The plants were irrigated with fresh water $\left(\mathrm{EC}=0.32 \mathrm{dSm}^{-1}\right)$ at three levels. Chemical analysis of fresh water used was presented in Table (2). Irrigation management included three irrigation levels. In the first level, soil was irrigated up to full field capacity (0.0DI), in the second; soil was irrigated up to 0.65 of full field capacity (0.35-DI), and up to 0.4 of full field capacity for the third level, representing 0.60-DI, at intervals of 3 to 4 days. Rational irrigation water requirements were calculated and have been showed in Fig (1).

\section{Salicylic acid application}

SA was dissolved in ethanol then added drop wise to water. The $\mathrm{pH}$ for all solutions was set at 6 . In Mid March (2012), Jatropha seedlings were foliar sprayed with three levels of salicylic acid $(0.0,5.0$ and $10 \mathrm{mM})$ at four-week intervals.

All plants were received $\mathrm{N}, \mathrm{P}$ and $\mathrm{K}$ fertilizers $(6: 10: 6)$ at a rate of $2.0 \mathrm{gL}^{-1}$. A micronutrient fertilizer was also supplement with a rate of $0.5 \mathrm{gL}^{-1}$. Fertilizers were applied 20 times (every 2 weeks).

Table (2): Chemical properties of the irrigation water

\begin{tabular}{|c|c|c|c|c|c|c|c|c|c|c|}
\hline \multirow{2}{*}{ Parameters } & \multirow{2}{*}{$\begin{array}{c}E C \\
d_{S} ~ m^{-1}\end{array}$} & \multirow[b]{2}{*}{ pH } & \multicolumn{4}{|c|}{ Soluble cations, meq $\mathbf{l}^{-1}$} & \multicolumn{4}{|c|}{ Soluble anions, meq $\mathbf{l}^{-1}$} \\
\hline & & & $\mathrm{Ca}^{2+}$ & $\mathrm{Mg}^{2+}$ & $\mathrm{Na}^{+}$ & $\mathbf{K}^{+}$ & $\mathrm{Cl}^{-}$ & $\mathrm{HCO}_{3}^{-}$ & $\mathrm{SO}_{4}{ }^{2-}$ & SAR* \\
\hline Fresh water & 0.32 & 7.95 & 0.97 & 0.60 & 1.64 & 0.39 & 1.50 & 1.30 & 0.80 & 1.85 \\
\hline
\end{tabular}

SAR: Sodium adsorption ratio

\section{Recorded vegetative properties}

Relative growth rate (RGR), calculated based on height according to Antúnez (2001); total leaf area (TLA) according to Pérez-Harguindeguy et al. (2013); leaf dry weight (LDW); leaf relative water content $\left(\mathrm{RWC}_{\mathrm{L}}\right)$ according to Yamasaki and Dillenburg (1999).

Nitrogen; phosphorus and potassium percentage in leaves

Samples were taken from third leaf from the plant apex, and dried at $70^{\circ} \mathrm{C}$ to constant weight. Total nitrogen percentage, was determined by micro-Kjeldahl as described by Jones (2001). Phosphorus percentage was estimated calorimetrically according by Mazumdar and Majumdar (2003). Potassium was determined using flame photometer according to Jones (2001).

\section{Total Chlorophyll}

Fresh leaf samples were taken from fully developed leaf (fourth leaf), then total chlorophyll were calculated as described by Porra et al. (1989).

\section{Data analysis}

Data were subjected to ANOVA using General Linear Model. Means of interaction effects were compared using Duncan at 5\% level of probability. Data were analyzed by SPSS program. As factorial experiment, treatments were performed in a randomized complete blocks design with three replications, three plants in each replicate. 


\section{RESULTS AND DISCUSSION}

Vegetative properties on juvenile stage $\left(1^{\text {st }}\right.$ and $2^{\text {nd }}$ years)

The vegetative growth of Jatropha at juvenile stage in Table (3) show the interaction between deficit irrigation (DI) and salicylic acid application (SA). Results indicated that most vegetative growth characters (i.e. total leaf area, leave dry weight and relative growth rate) were significantly affected by treatments, also, displayed a difference in the trends across successive years.

Table (3): Interaction effects of deficit irrigation levels (DI) and salicylic acid (SA) concentrations on vegetative growth characters of Jatropha at juvenile stage $\left(1^{\text {st }}\right.$ and $2^{\text {nd }}$ years $)$.

\begin{tabular}{|c|c|c|c|c|c|c|c|c|c|}
\hline \multirow[t]{2}{*}{ DI* } & \multirow[t]{2}{*}{$\underset{\mathbf{m M}}{\mathbf{S A}}$} & \multicolumn{2}{|c|}{$\begin{array}{l}\text { Relative growth rate } \\
\text { based on height } \\
\left.(\mathrm{cm} \mathrm{month})^{-1}\right)\end{array}$} & \multicolumn{2}{|c|}{$\begin{array}{c}\text { Total leaf area } \\
\left(\mathrm{cm}^{2}\right)\end{array}$} & \multicolumn{2}{|c|}{$\begin{array}{l}\text { Leaf dry weight } \\
\quad\left(\text { g plant }^{-1}\right)\end{array}$} & \multicolumn{2}{|c|}{$\begin{array}{l}\text { Leaf relative water } \\
\quad(\text { content \%) }\end{array}$} \\
\hline & & $1^{\text {st }}$ year & $2^{\text {nd }}$ year & $1^{\text {st }}$ year & $2^{\text {nd }}$ year & $1^{\text {st }}$ year & $2^{\text {nd }}$ year & $1^{\text {st }}$ year & $2^{\text {nd }}$ year \\
\hline & & \multicolumn{8}{|c|}{ Main effect of deficit irrigation levels (DI) } \\
\hline 0.0 & & $1.38^{\mathrm{a}}$ & $0.41^{\mathrm{b}}$ & $135.73^{\mathrm{a}}$ & $329.60^{c}$ & $0.38^{\mathrm{c}}$ & $0.97^{\mathrm{c}}$ & $77.94^{\mathrm{a}}$ & $77.23^{\mathrm{c}}$ \\
\hline 0.35 & & $1.20^{\mathrm{b}}$ & $0.86^{\mathrm{a}}$ & $129.60^{\mathrm{ab}}$ & $2213.77^{\mathrm{a}}$ & $1.51^{\mathrm{b}}$ & $1.70^{\mathrm{a}}$ & $84.79^{\mathrm{a}}$ & $85.77^{\mathrm{a}}$ \\
\hline 0.60 & & $1.25^{\mathrm{b}}$ & $0.78^{\mathrm{a}}$ & $117.87^{\mathrm{b}}$ & $1362.43^{b}$ & $2.52^{\mathrm{a}}$ & $1.36^{\mathrm{b}}$ & $82.05^{\mathrm{a}}$ & $82.29^{\mathrm{ab}}$ \\
\hline
\end{tabular}

Main effect of SA concentrations

\begin{tabular}{lllllllll}
\hline $\mathbf{0 . 0}$ & $1.16^{\mathrm{b}}$ & $1.21^{\mathrm{a}}$ & $122.13^{\mathrm{b}}$ & $3255.07^{\mathrm{a}}$ & $0.30^{\mathrm{b}}$ & $2.52^{\mathrm{a}}$ & $86.90^{\mathrm{a}}$ & $89.53^{\mathrm{a}}$ \\
$\mathbf{5 . 0}$ & $1.30^{\mathrm{a}}$ & $0.47^{\mathrm{b}}$ & $155.20^{\mathrm{a}}$ & $391.53^{\mathrm{b}}$ & $2.12^{\mathrm{a}}$ & $0.87^{\mathrm{b}}$ & $80.69^{\mathrm{ab}}$ & $79.26^{\mathrm{b}}$ \\
$\mathbf{1 0}$ & $1.37^{\mathrm{a}}$ & $0.38^{\mathrm{c}}$ & $105.87^{\mathrm{c}}$ & $259.20^{\mathrm{b}}$ & $1.98^{\mathrm{a}}$ & $0.64^{\mathrm{c}}$ & $77.18^{\mathrm{b}}$ & $76.50^{\mathrm{b}}$ \\
\hline
\end{tabular}

Interaction effect deficit irrigation levels (DI) and SA concentrations

\begin{tabular}{cccccccccc}
\hline & $\mathbf{0 . 0}$ & $1.14^{\mathrm{c}}$ & $0.47^{\mathrm{d}}$ & $104.01^{\mathrm{c}}$ & $437.20^{\mathrm{c}}$ & $0.43^{\mathrm{e}}$ & $1.79^{\mathrm{c}}$ & $85.10^{\mathrm{ab}}$ & $85.51^{\mathrm{abc}}$ \\
$\mathbf{0 . 0}$ & $\mathbf{5 . 0}$ & $1.58^{\mathrm{a}}$ & $0.38^{\mathrm{d}}$ & $185.62^{\mathrm{a}}$ & $360.80^{\mathrm{c}}$ & $0.31^{\mathrm{e}}$ & $0.61^{\mathrm{efg}}$ & $77.02^{\mathrm{ab}}$ & $76.42^{\mathrm{bc}}$ \\
& $\mathbf{1 0}$ & $1.42^{\mathrm{ab}}$ & $0.38^{\mathrm{d}}$ & $117.61^{\mathrm{c}}$ & $190.80^{\mathrm{c}}$ & $0.39^{\mathrm{e}}$ & $0.52^{\mathrm{g}}$ & $71.76^{\mathrm{b}}$ & $69.86^{\mathrm{c}}$ \\
& $\mathbf{0 . 0}$ & $1.14^{\mathrm{c}}$ & $1.76^{\mathrm{a}}$ & $150.43^{\mathrm{b}}$ & $576.90^{\mathrm{a}}$ & $0.25^{\mathrm{e}}$ & $3.38^{\mathrm{a}}$ & $87.25^{\mathrm{ab}}$ & $92.95^{\mathrm{a}}$ \\
$\mathbf{0 . 3 5}$ & $\mathbf{5 . 0}$ & $1.19^{\mathrm{bc}}$ & $0.47^{\mathrm{cd}}$ & $158.41^{\mathrm{b}}$ & $484.30^{\mathrm{c}}$ & $3.24^{\mathrm{b}}$ & $0.89^{\mathrm{de}}$ & $85.47^{\mathrm{ab}}$ & $83.66^{\mathrm{abc}}$ \\
& $\mathbf{1 0}$ & $1.28^{\mathrm{bc}}$ & $0.36^{\mathrm{d}}$ & $80.04^{\mathrm{d}}$ & $388.00^{\mathrm{c}}$ & $1.03^{\mathrm{d}}$ & $0.83^{\mathrm{def}}$ & $81.64^{\mathrm{ab}}$ & $80.69^{\mathrm{abc}}$ \\
& $\mathbf{0 . 0}$ & $1.19^{\mathrm{bc}}$ & $1.39^{\mathrm{b}}$ & $112.01^{\mathrm{c}}$ & $355.90^{\mathrm{b}}$ & $0.22^{\mathrm{e}}$ & $2.40^{\mathrm{b}}$ & $88.36^{\mathrm{a}}$ & $90.15^{\mathrm{ab}}$ \\
$\mathbf{0 . 6 0}$ & $\mathbf{5 . 0}$ & $1.14^{\mathrm{c}}$ & $0.57^{\mathrm{c}}$ & $121.65^{\mathrm{c}}$ & $329.50^{\mathrm{c}}$ & $2.80^{\mathrm{c}}$ & $1.12^{\mathrm{d}}$ & $79.59^{\mathrm{ab}}$ & $77.71^{\mathrm{abc}}$ \\
& $\mathbf{1 0}$ & $1.42^{\mathrm{ab}}$ & $0.39^{\mathrm{d}}$ & $120.07^{\mathrm{c}}$ & $198.80^{\mathrm{c}}$ & $4.53^{\mathrm{a}}$ & $0.56^{\mathrm{fg}}$ & $78.21^{\mathrm{ab}}$ & $79.00^{\mathrm{abc}}$ \\
\hline
\end{tabular}

$* 0.0 \mathrm{DI}=100 \%$ soil field capacity; $0.35-\mathrm{D}=65 \%$ soil field capacity and $0.60-\mathrm{D}=40 \%$ soil field capacity

Means followed by the same superscript letters are not significantly different at $\mathrm{P}<0.05$ according to Duncan's multiple test

The most effective treatment for growth characters was found when plants irrigated with fresh water at 0.35 -DI without significant difference with those at 0.0 DI treatments, particularly, with SA spraying at 5.0 $\mathrm{mM}$. Data indicated that, SA application either at 5.0 or $10.0 \mathrm{mM}$ resulted in negative impact on plant growth, when plants subjected to 0.0 -DI.

This result is in good agreement with that reported by Pérez -Vazquez et al (2013), who found that total dry matter at $0.6,0.4$, and $0.2-\mathrm{DI}$, were statistically similar, but different from 0.9 and 0.80 -DI. On the other hand, reduction in the same vegetative characters under 0.6-DI ( 0.4 field capacity) was agreed to somewhat with that obtained by Jayasundara et al. (2014). Reyadh (2002) concluded that Jatropha can stand long periods of drought by shading most of its leaves to reduce transpiration loss, while Jamieson et al. (1995) and Najafian et al. (2009) reported that in case of water shortage, stomata closure, resulting in decreased transpiration. Salicylic acid is a central compound in the 
defense of closing stomata in several species. Jatropha species is easy to establish as it has a fast growth, requires minimal amounts of water and survives in poor soils (Valdes et al., 2011). High temperatures which happened several times may led to high water consumption compared to what happened for evapotranspiration $\left(\mathrm{ET}_{0}\right)$ values. The present study suggests that SA exogenous application may help reduce the adverse effects of drought in Jatropha plants. Data clearly showed that foliar spraying of plants with different SA concentrations improved different growth traits (Table 3). Foliar-applied SA-increased growth characteristics in Jatropha plants was similarly observed earlier for some herbaceous plants (Saruhan et al., 2012; Fayez and Bazaid, 2014). The ability of SA to increase plant dry mass, alleviating the adverse effect of DI stress, may have substantial contributions in improving plant growth and overcoming the yield barrier resulting from adverse conditions.

Nitrogen; phosphorus; potassium and total chlorophyll in leaves $\left(2^{\text {nd }}\right.$ years $)$

Data in Table (4) indicates that $\mathrm{P} \%$ was higher with 0.35 -DI than 0.0 or 0.6 -DI under all levels of SA. $\mathrm{N} \%$ data indicated that the most effective treatment was found when Jatropha sprayed with $5.0 \mathrm{mM}$ SA under irrigation with water $0.35 \mathrm{DI}$; also it is noted from Table (4) that K\% with $10.0 \mathrm{mM} \mathrm{SA}$ treatment was higher than that with 0 and $5 \mathrm{mM}$, under all levels of DI. Data obtained by Najafian et al. (2009) showed that SA treated plants had greater shoot and root dry weights, since SA increased photosynthetic rates and nutrient uptake.

Table (4): Interaction effects of deficit irrigation levels (DI) and salicylic acid (SA) concentrations on nitrogen \%, phosphorus $\%$, potassium $\%$, and total chlorophyll content on leaves of Jatropha at juvenile stage ( $2^{\text {nd }}$ years)

\begin{tabular}{|c|c|c|c|c|c|}
\hline \multicolumn{2}{|c|}{ Treatments } & \multirow[b]{2}{*}{$\mathbf{N} \%$} & \multirow[b]{2}{*}{$\mathbf{P} \%$} & \multirow[b]{2}{*}{$\mathbf{K} \%$} & \multirow{2}{*}{$\begin{array}{c}\text { Total Chlorophyll } \\
\text { mg g }^{-1}\end{array}$} \\
\hline DI* & $\begin{array}{c}\mathrm{SA} \\
(\mathbf{m M})\end{array}$ & & & & \\
\hline & & \multicolumn{4}{|c|}{ Main effect of deficit irrigation levels (DI) } \\
\hline 0.0 & & $3.56^{\mathrm{a}}$ & $0.20^{\mathrm{c}}$ & $1.05^{\mathrm{b}}$ & $0.26^{\mathrm{b}}$ \\
\hline 0.35 & & $3.79^{\mathrm{a}}$ & $0.37^{\mathrm{a}}$ & $1.40^{\mathrm{a}}$ & $0.38^{\mathrm{a}}$ \\
\hline \multirow[t]{5}{*}{0.60} & & $3.77^{\mathrm{a}}$ & $0.24^{\mathrm{b}}$ & $0.79^{\mathrm{c}}$ & $0.17^{\mathrm{a}}$ \\
\hline & & \multicolumn{4}{|c|}{ Main effect of SA concentrations } \\
\hline & 0.0 & $3.55^{\mathrm{a}}$ & $0.25^{\mathrm{b}}$ & $0.63^{\mathrm{c}}$ & $0.21^{\mathrm{c}}$ \\
\hline & 5.0 & $3.80^{\mathrm{a}}$ & $0.29^{\mathrm{a}}$ & $0.95^{\mathrm{b}}$ & $0.33^{\mathrm{a}}$ \\
\hline & 10 & $3.78^{\mathrm{a}}$ & $0.28^{\mathrm{ab}}$ & $1.67^{\mathrm{a}}$ & $0.27^{\mathrm{b}}$ \\
\hline & & \multicolumn{4}{|c|}{ Interaction effect deficit irrigation levels (DI) and SA concentrations } \\
\hline \multirow{3}{*}{$\mathbf{0 . 0}$} & 0.0 & $3.36^{\mathrm{b}}$ & $0.288^{\mathrm{c}}$ & $0.48^{\mathrm{e}}$ & $0.23^{\mathrm{d}}$ \\
\hline & 5.0 & $3.322^{\mathrm{b}}$ & $0.12^{\mathrm{e}}$ & $0.52^{\text {de }}$ & $0.26^{\mathrm{cd}}$ \\
\hline & 10 & $4.0^{\mathrm{ab}}$ & $0.20^{\mathrm{d}}$ & $2.16^{\mathrm{a}}$ & $0.30^{c}$ \\
\hline \multirow{3}{*}{0.35} & 0.0 & $3.92^{\mathrm{ab}}$ & $0.20^{\mathrm{d}}$ & $0.5^{\mathrm{e}}$ & $0.27^{\mathrm{cd}}$ \\
\hline & 5.0 & $4.1^{\mathrm{a}}$ & $0.52^{\mathrm{a}}$ & $1.6^{\mathrm{b}}$ & $0.51^{\mathrm{a}}$ \\
\hline & 10 & $3.36^{\mathrm{b}}$ & $0.4^{\mathrm{b}}$ & $2.1^{\mathrm{a}}$ & $0.36^{\mathrm{b}}$ \\
\hline \multirow{3}{*}{0.60} & 0.0 & $3.36^{\mathrm{b}}$ & $0.26^{\mathrm{cd}}$ & $0.9^{c}$ & $0.13^{\mathrm{e}}$ \\
\hline & 5.0 & $3.97^{\mathrm{ab}}$ & $0.24^{\mathrm{cd}}$ & $0.74^{\mathrm{cd}}$ & $0.23^{\mathrm{d}}$ \\
\hline & 10 & $3.97^{\mathrm{ab}}$ & $0.24^{\mathrm{cd}}$ & $0.74^{\mathrm{cd}}$ & $0.14^{\mathrm{e}}$ \\
\hline
\end{tabular}

$* 0.0 \mathrm{DI}=100 \%$ soil field capacity; $0.35-\mathrm{D}=65 \%$ soil field capacity and $0.60-\mathrm{D}=40 \%$ soil field capacity

Means followed by the same superscript letters are not significantly different at $\mathrm{P}<0.05$ according to Duncan's multiple test

Concerning chlorophyll concentration, data indicated that the most effective treatment was found when Jatropha irrigated with water of $0.35 \mathrm{DI}$, and sprayed with $5.0 \mathrm{mM}$ SA. As stress increases, chlorophyll content decreases faster than other pigments (Bannari et al., 2007). In this concern Singh and Usha (2003) reached the conclusion that wheat plants treated with SA and subjected to water stress exhibited, in general, higher total chlorophyll content, moisture content. Also Hasan et al. (2008) concluded that SA enhanced significantly the photosynthetic parameters, chlorophyll and relative water contents under water stress. The photosynthetic pigments are important to plants. Chlorophylls are the major chloroplast 
components for photosynthesis, and the relative chlorophyll content presents a positive correlation with photosynthetic rate. The decrease in chlorophyll content under drought stress has been considered a typical symptom of oxidative stress and may be the result of pigment photo-oxidation and chlorophyll degradation (Bogeat-Triboulot et al., 2007). Rao et al. (2012) conducted a study to perceive the protective role of SA in maize plants under water deficit. They concluded that relative water content, leaf membrane stability index, chlorophyll and potassium content were significantly higher in plants treated with SA. These studies confirmed the mentioned results.

\section{Irrigation water requirements}

According to meteorological data, root effective depth of Jatropha, Jatropha-crop coefficient (obtained by Hokam and Abo El-Soud (2016) and soil moisture measurements were involved in obtaining the results showed in Fig (1). Generally, results showed that water requirements for both 0.0 and 0.35 -DI treatments were increased about 5 times for the second year compared to the first one. The maximum water consumption was occurred through July to October. The data listed included the actual irrigation water requirements at 0.0 -DI level, could be greatly saved when applied under 0.35-DI level. Thus, under 0.35DI level, and assuming that each feddan included 640 shrubs, $144 \mathrm{~m}^{3}$ of water could be saved from one hectare. According to the results obtained by PerezVazquez et al. (2013), such amount of saved water could be reached $423 \mathrm{~m}^{3} \mathrm{ha}^{-1}$.

\section{CONCLUSION}

Remarkable efforts have been made with the goal of developing mechanisms for helping plants to rectify the adverse effects of water scarce and drought. These mechanisms include following DI strategy and the exogenous application of specific growth regulators to the plants. Studies have shown that spraying plants that subjected to DI with SA is an 'effective corrective agent. The bioenergy crop Jatropha can grow and produce good yield under minimum water requirements compared to other crops. The most effective treatment that accelerate vegetative growth at juvenile stage $\left(1^{\text {st }}\right.$ and $2^{\text {nd }}$ years) under DI treatments was performed when Jatropha under 0.35 -DI (0.65 of full field capacity). Application of $5 \mathrm{mM}$ SA was positively affected vegetative growth characters.

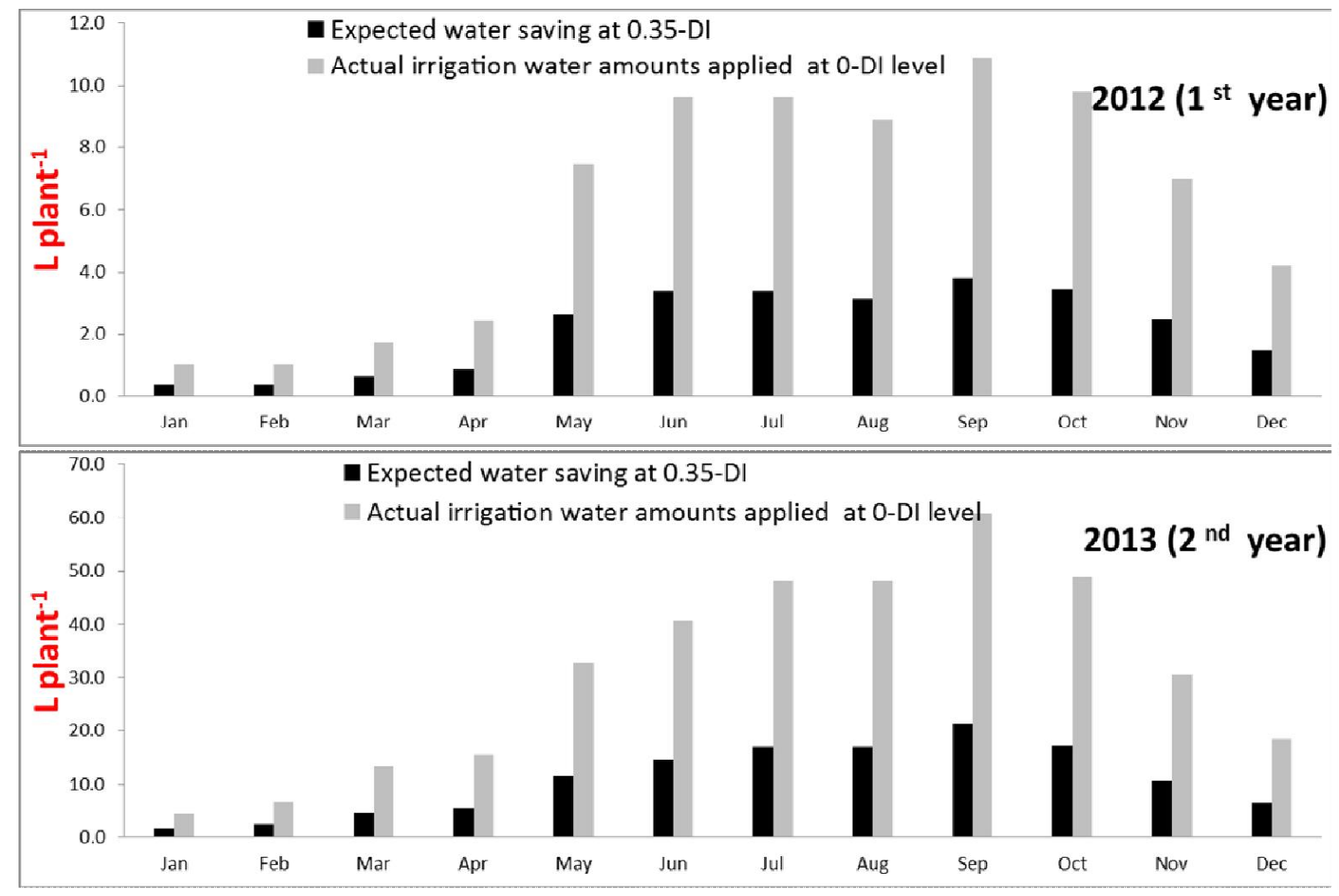

Fig 1 : Actual irrigation water amounts applied at 0 -DI level, and expected water saving at 0.35 -DI at juvenile stage $\left(1^{\text {st }}\right.$ and $2^{\text {nd }}$ years).

The efficiency of exogenous SA action depended on the SA concentrations getting the best result in the plants treated with $5 \mathrm{mM} \mathrm{SA}$. Therefore, we are able to conclude that foliar application of $5 \mathrm{mM}$ SA could be used as a potential chemical priming strategy to Jatropha drought tolerance

The increase in LDW after one year from DI strategy in response to SA application could be attributed to the induction of antioxidant responses that protect plant from damage (Singh and Usha, 2003). The ability of SA to increase plant dry mass, alleviating the adverse effect of DI stress, may have substantial contributions in improving plant growth and overcoming the yield barrier resulting from adverse conditions. 
Result is logic because the shortage of water supply affects various biological processes in plant such as photosynthetic efficiency, membrane stability and gas exchange characteristics, assimilates translocation, plant dry weight as well as the contents of total soluble sugar, starch, amino acids and protein etc. (Sohrabi et al., 2012; Wu et al., 2013).

For such study conditions it is recommended to apply deficit irrigation strategy especially at $0.35 \mathrm{DI}$ level in order to reduce great amounts of irrigation water.

\section{REFERENCES}

Ahmad, S. and S. M. Sultan (2015). Physiological changes in the seeds of Jatropha curcas L. at different Stages of fruit maturity. Braz. arch. biol. Technol., 58(1): 118-123.

Antúnez, I. (2001). Relative growth rate in phylogenetically related deciduous and evergreen woody species. Oecologia, 128: 172-180.

Bannari, A., K. S. Khurshid, K. Staenz and J. W. Schwarz (2007). A comparison of hyperspectral chlorophyll indices for wheat crop chlorophyll content estimation using laboratory reflectance measurements. IEEE Trans. Geosci. Remote Sensing, 45: 3063-3074.

Bogeat-Triboulot M-B, M. Brosché, J. Renaut, L. Jouve, and E. Dreyer (2007). Gradual soil water depletion results in reversible changes of gene expression, protein profiles, ecophysiology, and growth performance in Populus euphratica, a poplar growing in arid regions. Plant Physiology, 143: 876-892.

Dehgan, B. (2012). Jatropha (Euphorbiaceae). Flora Neotropica Monograph, 110: 1-273.

Fayez K. A. and S. A. Bazaid (2014). Improving drought and salinity tolerance in barley by application of salicylic acid and potassium nitrate. J. Saudi Soc. Agri. Sci., 13: 45-55.

Fereres, E. and M. A. Soriano (2007). Deficit irrigation for reducing agricultural water use. J Exp Bot., 58(2): 147-159.

Hasan, H. S., Q. Fariduddin and A. Ahmad (2008). Growth of tomato (Lycopersicon esculentum) in response to salicylic acid under water stress. Journal of Plant Interactions, 3: 297-304.

Hasanuzzaman M., K. Nahar, S. S. Gill and M. Fujita (2013). "Drought stress responses in plants, oxidative stress, and antioxidant defense," In: Climate Change and Plant Abiotic Stress Tolerance. Tuteja N. and S. S. Gill (eds). Weinheim: Wiley-VCH Verlag $\mathrm{GmbH} \& \mathrm{Co}$. KGa A; 209-250.

Hokam, E. M. and I. H. Abo El-soud (2016). Evaluation of growth parameters for Jatropha curcas L. (Biofuel Plant) under salinity and water stress using tensiometer for irrigation guiding. Egyptian Journal of Soil Science, 56: In press.

Hoogeveen, J., J. M. Faure and N. Van De Giessen (2009). Increased biofuel production in the coming decade: to what extent will it affect global freshwater resources? Irrig. and Drain, 58: $148-160$.

Jamieson, P. D, G. S. Francis, D. R. Wilson and R. J. Martin (1995). Effects of water deficits on evapotranspiration from barley. Agricultural and Forest Meteorology, 76(1): 41-58.

Jayasundara, N. Y., L. Galagedara, W. Pushpakumara and J. Weerahewa (2014). Effect of soil moisture content on Jatropha curcas L. during early growth stage., SAITM Research Symposium on Engineering Advancements 2014 (SAITM RSEA, 53-57

Jewitt, G.P.W., H. W. Wen, R. P. Kunz and A. M. Van Rooyen (2009). Scoping Study on Water Use of Crops/Trees for Biofuels in South Africa. Report to the Water Research Commission, WRC Report No. 1772/1/09 (ISBN 978-1-77005-8842).

Jones, Jr. J.B. (2001). Laboratory Guide for Conducting Soil Tests and Plant Analysis. CRC Press, Washington, DC., USA., pp 384.

Khan, M. I. R., M. Fatma, T. S. Per, N. A. Anjum and N. A. Khan (2015). Salicylic acid-induced abiotic stress tolerance and underlying mechanisms in plants Plant Sci., 6: 462.

Kumar, A. and S. Sharma (2008). An evaluation of multipurpose oil seed crop for industrial uses (Jatroph curcas L.). Industrial Crops and Products, 28: $1-10$.

Mazumdar, B. C. and K. Majumder (2003). Methods of Physiochemical Analysis of Fruits. Daya Publishing House Delhi, India.

Najafian, S., M. Khoshkhui, V. Tavallali and M. J. Saharkhiz (2009). Effect of salicylic acid and salinity in thyme (Thymus vulgaris L.): Investigation on changes in gas exchange, water relations, and membrane stabilization and biomass accumulation. Aust. J. Basic. Applied Sci., 3: 2620-2626.

Pérez-Harguindeguy N., S. Díaz, E. Garnier, S. Lavorel and J. H. C. Cornelissen (2013). New handbook for standardised measurement of plant functional traits worldwide. Australian Journal of Botany, 61: 167-234.

Pérez-Vazquez, A., G. Hernández-Salinas, C. ÁvilaReséndiz, O. A. Valdés-Rodríguez, F. GallardoLópez, E. García-Pérez and O. Ruiz-Rosado, (2013). Effect of the soil water content on Jatropha seedlings in a tropical climate. Int. Agrophys., 27: 351-357.

Porra, R. J., W. A. Thompson and P. E. Kreidemann (1989). Determination of accurate extinction coefficients and simultaneous equations for assaying chlorophylls $\mathrm{a}$ and $\mathrm{b}$ extracted with four different solvents. Biochim Biophys Acta, 975: 384-394.

Pullaiah, T. and B. Bahadur (2013). Economic and Medicinal Importance of Jatrophas. In "Jatropha, Challenges for a New Energy Crop - Volume 2" Edited by B. Bahadur; M. Sujatha and N. Carels. Springer NewYork Heidelberg Dordrecht London. Pp. 187-218. 
Rajagopal, D. and D. Zilberman (2007). Review of Environmental, Economic and Policy Aspects of Biofuels. Policy Research Working Paper WPS4341, Development Research Group, The World Bank, September.

Rao, S. R., A. Qayyum, A. Razzaq, M. Ahmad, I. Mahmood and A. Sher (2012). Role of foliar application of salicylic acid and L-tryptophan in drought tolerance of maize. The Journal Animal and Plant Sciences, 22: 768-772.

Reyadh, M. (2002). The cultivation of Jatropha curcas in Egypt. Undersecretary of State for Forestation, Ministry of Agriculture and Land Reclamation. Retrieved from http://www.fao. org/docrep/x5402e/x5402e11.htm.

Sahu, G. K. (2013). Salicylic Acid: Role in Plant Physiology and Stress Tolerance. In Molecular Stress Physiology of Plants. Edited by Rout, G.R. and A. B. Das. Springer Dordrecht Heidelberg New York London. Pp. 217-240.

Saruhan N, A. Saglam and A. Kadioglu (2012). Salicylic acid pretreatment induces drought tolerance and delays leaf rolling by inducing antioxidant systems in maize genotypes. Acta Physiol Plant, 34: 97-106.

Singh, B and K. Usha (2003). Salicylic acid induced physiological and biochemical changes in wheat seedlings under water stress. Plant Growth Regul., 39: 137-141.

Sohrabi, Y., G. Heidari, W. Weisany, K. Golezani and K. Mohammadi (2012). Some physiological responses of chickpea (Cicer aritinum L.) cultivars to arbuscular mycorrhiza under drought stress. Russ J Plant Physiol, 59(6): 708-716.

Valdes, R. O. A., S. O. Sanchez, V. A. Perez and B. R. Ruiz (2011). Soil texture effects on the development of Jatropha curcas seedlingsMexican veriety 'Piñon manso'. Biomass Bioenery, 35:3529-3536.

Wu B. H., N. Niu, J. H. Li and S.-H Li (2013). Leaf fruit ratio affects the proteomic profile of grape berry skins. J. Am. Soc. Hortic. Sci., 138: 416427.

Yamasaki, S. and L. R. Dillenburg (1999). Measurements of leaf relative water content in Araucaria angustifolia. Revista Brasileira de Fisiologia Vegetal, 11(2): 69-75.

\section{تأثير استراتيجية الري المتناقص و الرش بحمض السالسيلك علي نمو نبات الجتروفا

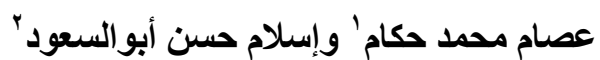

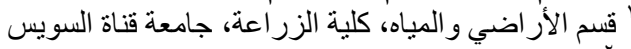

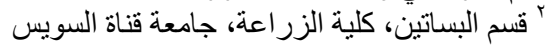

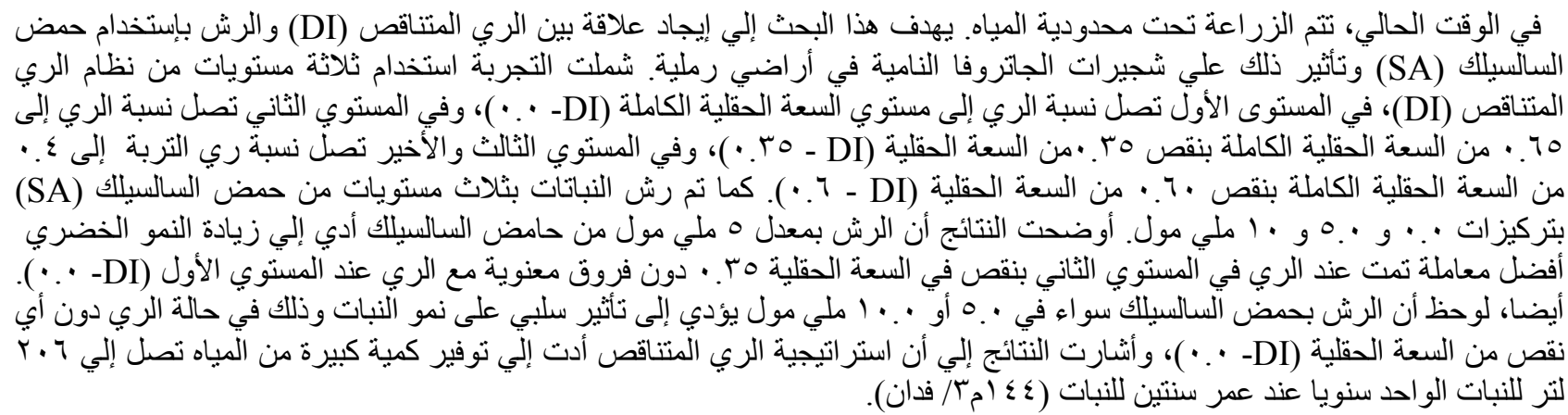

